Benares has paid particular attention to the teaching of science, both pure and applied. The science departments with a staff of seventy provide accom. modation for about one thousand students, and these departments have now been constituted a separate College of Science within the University. This College, of which Prof. K. K. Mathur has been appointed the first Principal, was formally opened on September 12 by the veteran Vice-Chancellor and founder of the University, Pandit M. M. Malaviya. In his opening address, the Vice-Chancellor emphasised the need in the present economic position of India for increased facilities for the study of science in all its branches. The Hindu University has already played a prominent part in the industrial development of the United Provinces, and we are sure that the foresight of the Vice-Chancellor and executive body of the University in establishing this new college will lead to an expansion of its activities.

\section{New German renderings of 'Foreign' Words}

IN NATURE of September 28, p. 495, we published a short notice of the second edition of "Theoretische Physik" by Dr. Georg Joos. Our reviewer commented very favourably upon the book, but animadverted upon the addition of a glossary of "foreign" words (Erlaüterung einiger Fremdwörter), "in which Absorption (Verschluckung), Elastizität (Dehnbarkeit), Kapillarität (Haarröhrchenkraft) and such-like non-Prussian, words are translated into the new German, although these 'foreign' words appear in the articles in Gehler's 'Physikalisches Worterbuch' of more than a hundred years ago". We have now received an indignant letter from Dr. Joos, containing the following explanation of this glossary. "Many English readers, who according to the reporter are to be impressed comically through these things, will know that the graduates of the 'Oberrealschule' have studied neither Latin nor Greek and that for them an explanation of these words is very desirable", adding, "According to the wording of the report the reader must think that it is my intention to seriously substitute 'Verschluckung' for 'Absorption' or 'Segelstange' for 'Antenne'". As regards the last sentence our reviewer suggested nothing about Dr. Joos' intentions, but stated the bare fact that the glossary had been added to the book, leaving his English readers free (if we may use the word without offence) to draw any conclusions they wished. Many will, no doubt, share his and our surprise that words which have been in regular use in the German language for four generations and more, a period sufficient, we should have thought, to guarantee their incorporation, should be regarded and named as foreign.

OuR reviewer adds : "We note that graduates of the Oberrealschule have studied neither Latin nor Greek, but then they did not do so at the time of the first edition, which did not contain the glossary ; in fact, they never did. Most students in England and other countries are equally unfamiliar with Latin and Greek, but have no difficulty over 'elasticity' and 'capillarity', while Germans unfamiliar with French have, we believe, no difficulty over 'General' and 'Soldat'. Dr. Joos does not seem to realise that, if there is any force in his contention, most German students will not know what his book is about, since both 'Theoretische' and 'Physik' are Greek words not explained in the Erläuterung. For that matter, Electricität (may we suggest Bernsteinreibungskraft?) is not in the glossary, although Kapazität (Fassungsvermögen) is: Alkali (a Semitic word which occurs in the book combined with a Latin word as Alkalispektren - shall we suggest Pflanzenaschenerde. lichterscheinung?) is missing, although Kondensator (Verdichter) is included. We hope in the next edition to see the glossary either omitted or properly completed. We in England find so much in the presentday activities in German universities to move us to tears that Dr. Joos really must allow us a faint smile when we come across something harmlessly amusing from that quarter, and permit us to be our own judges of what is 'comical'".

\section{International Exhibition of Nature Photography}

THERE was a large assembly of naturalists and Nature photographers at the opening on October 16 of the Country Life International Exhibition of Nature Photography at the British Museum (Natural History), Cromwell Road, South Kensington. The Earl of Onslow, president of the Society for the Protection of the Fauna of the Empire, referred to the great value of Nature photography and cinematography as "a very powerful incentive towards the preservation of wild life in all its forms", and to the fact that the Exhibition contains a large number of subjects that have never been seen before. He went on to remark that "there is a very grave danger at present hanging over us and that is that unless wild animals, big-game and birds of all kinds are carefully preserved a great number of species will become extinct and they will be a downright loss to the world in general. We could do without poison snakes but most other animals are a very valuable asset not only from the natural history point of view, but from the scientific point of view and from the point of view that they tend to preserve the balance of Nature." The audience, which included, among many others well known for their interest in wild life, the Duke of Sutherland and Lord Desborough, afterwards inspected the Exhibition. More than thirteen hundred photographs are displayed on screens in the Whale Hall, one wall being devoted entirely to the work of pioneer photographers, which includes the late J. H. Symonds" picture "Goldfinches fighting on Teazle", "Marsh Harrier" by the late Col. $H$. Moore, and no fewer than seventeen fine studies by Mr. C. J. King. The Exhibition will be open-admission free-until November 30 . A souvenir volume (5s.), contrining reproductions of 120 pictures from the Exhibition, has been published.

\section{Edwin Klebs}

IN a centennial note published in the New England Journal of Medicine of July 11, Dr. Leona Baum. gartner, of Cornell University Medical College, New York, claims that Edwin Klebs, who was born 